\title{
Stem cells are on the House
}

Tre

he US House of Representatives recently passed a bill that will allow federal funding to be used to support research utilizing newly derived human ES cell lines.

Current legislation, passed by President Bush on August 9, 2001, limits federal funding of human ES cell research to studies using ES cell lines collected from embryos that were destroyed before that date. However, researchers believe that the 21 cell lines that fulfill this criterion have various problems that might make them unsuitable for some studies; for example, several of these cell lines have been shown to exhibit genetic instability in certain conditions (1). The new legislation should overcome these problems because it would allow researchers to seek federal funding to use the many ES cell lines more recently privately derived from embryos discarded by fertility clinics.

However, before the bill is passed into law it needs to be approved by both the Senate and President Bush. At press time, the Senate was set to debate this bill in February and, as it is identical to one passed in the last two years by both the House of Representatives and the Senate, most observers think that the Senate is likely to approve it.

By contrast, President Bush vetoed the bill last year. And given that the White House response to the newly passed bill was negative, stating that "Whatever one's view of the ethical issues or the state of the research, the future of this field does not require a policy of Federal subsidies that is offensive to the moral principles of millions of Americans" (2), it is possible that President Bush will veto the bill a second time. However, Representative Diana DeGette (D-CO), cosponsor of the bill passed by the House of Representatives, told the JCI, "We brought this legislation back for a vote to give President Bush another chance to do the right thing. I would still welcome the opportunity to sit down with the President to discuss the importance of this life-saving research. It is not too late for President Bush to do the right thing and say yes to cures."

The number of affirmative votes that the bill received in the House of Repre- sentatives was fewer than the two-thirds majority required to override any presidential veto (although support for the bill had increased by 15 votes from last time), so the future of this bill looks set for more debate and political wrangling. However, what supporters of the bill are hoping, as articulated to the JCI by DeGette, is that because "the American people clearly support scientific funding and the use of ES cells to address some of our most debilitating diseases, it is time for President Bush to allow this groundbreaking research to move forward."

DeGette's contention that the use of federal funding for ES cell research has

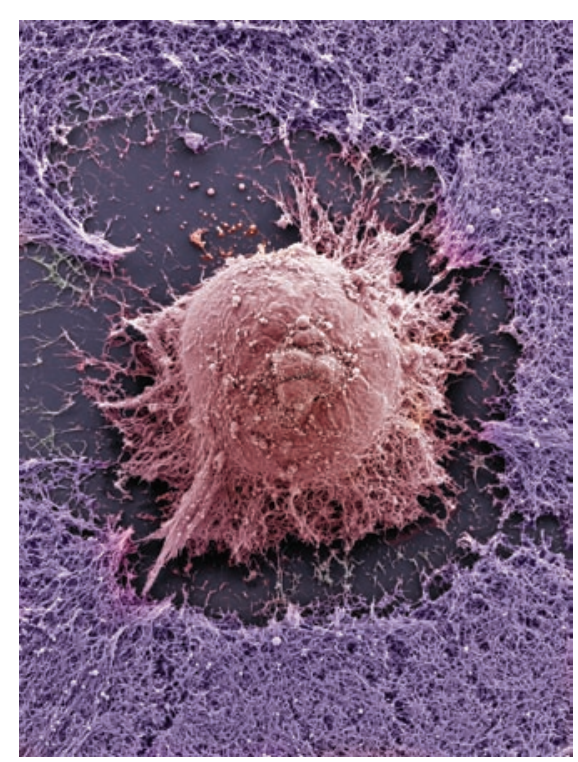

\section{Figure 1}

Federal funding might soon be used for research utilizing any human ES cell line. Image reproduced with permission from Photo Researchers Inc.

the support of the public is substantiated by polls conducted last year, in which $50 \%-60 \%$ of those polled supported this initiative (3). Public support for ES cell research was also apparent in the November 2006 midterm elections, when senatorial candidates such as Claire McCaskill (D) in Missouri, whose campaign vociferously supported ES cell research, were elected to office and one of the biggest opponents of ES cell research, incumbent Senator Rick Santorum (R-PA), lost his bid to retain his seat. Furthermore, voters in Missouri also approved a separate ballot measure that prevents lawmakers from barring work on ES cells.

The passing of the Missouri bill was greeted with enthusiasm by researchers in the state because, as Steven Teitelbaum - an expert in bone research at Washington University, St. Louis, who campaigned for many years to get this bill on the ballot - told the JCI, "it removes the possibility that proposals discussed in the Missouri House and Senate that would criminalize both ES cell research and any patients that might receive ES cell-based therapeutics might become law." Teitelbaum also expressed hope that this bill would help attract outstanding scientists to Missouri.

However, Teitelbaum was keen to stress that, despite the approval at the ballot box in one of the most conservative states in the country, there is still a long way to go before ES cell research no longer generates such intense debate and division, adding that "it is essential that researchers do not hype the potential of ES cell-based therapeutics just to answer their critics," an accusation he and other researchers have leveled at David Prentice, an opponent of ES cell research who often claims that adult stem cells provide treatments for 65 human illnesses (4).

Although there is much work to be done before ES cell-based therapeutics are used in patients, the passing of this bill will align federal funding regulations with the law, which does not block ES cell research.

\section{Karen Honey}

1. Draper, J.S., et al. 2004. Recurrent gain of chromosomes $17 \mathrm{q}$ and 12 in cultured human embryonic stem cells. Nat. Biotechnol. 22:53-54.

2. Executive Office of the President. January 11, 2007. Statement of administration policy. http:// www.whitehouse.gov/omb/legislative/sap/110-1/ hr3sap-h.pdf

3. PollingReport.com. The origin of human life. http://www.pollingreport.com/science.htm.

4. Smith, S., Neaves, W., and Teitelbaum, S. 2006. Adult stem cell treatments for diseases? Science. 313:439. 